\title{
Screening of Rice Blast Resistance Genes from Aromatic Rice Germplasms with SNP Markers
}

\author{
Jeong-Soon Kim ${ }^{1}$, Sang-Nag Ahn' ${ }^{2}$, Chung-Kon Kim ${ }^{1}$ and Chang-Ki Shim ${ }^{1 *}$ \\ ${ }^{1}$ National Agrobiodiversity Center, Rural Development Administration, Suwon 441-100, Korea \\ ${ }^{2}$ Depatment of Agronomy, Chungnam National University, Daejeon 305-764, Korea \\ (Received on December 1, 2009; Accepted on February 15, 2010)
}

Rice blast is one of the serious devastating diseases. This study was carried out to determine the genetic diversities of blast resistance $(R)$ genes form 86 accessions of aromatic rice with eight SNP markers, z4792, zt4792, z60510, zt6057, k6415, k6411, k39575 and t256, which showed the close-set linkage to 6 major genes, Piz, Piz-t, Pik, Pik-m, Pik-p, and Pit. Four accessions of indica type, Mayataung, Yekywin Yinkya Hmwe, Basmati9-93, and Basmati5854, showed the positive amplicons of six major genes. Among 86 accessions, 83 accessions were detected both or one of Piz and Piz-t genes. Seventy three accessions contained the $P i z$ gene with $\mathbf{z 4 7 9 2}$ marker. In addition, 30 and 71 accessions possessed $P$ iz-t gene with zt4792 and zt6057 markers, respectively. Ten accessions showed the positive bands for the Piz-t gene with both zt4792 and zt6057 markers. Only one accession, Khau Nua Keo, was not amplified for both $\mathrm{Piz}$ and Piz-t gene. But japonica type, Gerdeh, possessed only $\mathrm{Piz}$ gene between $\mathrm{Piz}$ and $\mathrm{Piz}-\mathrm{t}$. Fifty two accessions showed the three of Pik multiple genes and Pit gene. Four accessions, Iari7447, Daebunhyangdo2, Shiyayuuine, and Basmati 6129 possessed a Pik-p gene. Especially, Pit gene on chromosome 1 was detected with $\mathbf{2 5 6}$ marker in all of 83 accessions, exception of A-2, one accession of japonica type.

Keywords : aromatic rice, $P i$ genes, rice blast resistance, SNP marker

Aromatic rices (Oryza sativa L.) such as 'Basmati', 'Kelara', and 'Jasmine' are known for their fragrance when cooked. Also, they fetch a premium price in domestic and world markets, often three to four times more than that of the ordinary rice varieties. In Korea, seven varieties of aromatic rice, Hyangmibyeo1ho, Hyangmibyeo2ho, Hyangnambyeo, Aranghyangchalbyeo, Mihyangbyeo, Seolhyangchalbyeo, and Heughyang were bred from 1993 to 2000 (Choi et al., 1995; Ha et al., 2003; Ha et al., 2006;

\footnotetext{
*Corresponding author.

Phone)+82-31-299-1878, FAX) +82-31-299-1893

E-mail)ckshim@korea.kr
}

Moon et al., 1998; Moon et al., 2003).

Rice blast disease, caused by Magnaporthe grisea, causes economically significant yield losses annually worldwide and has been one of the most serious diseases of rice because of their pathogenic complexity related pathogen, host, and micro weather (Kwon and Lee, 2002; Lee, 1994; Li et al., 2007; Ou, 1985; Teng et al., 1991).

Especially, the blast fungus is highly variable and numerous; races of blast fungus are present in most field conditions (Ou, 1979; Xia et al., 1993; Valent and Chumley, 1994). The identification and isolation of additional host $R$ genes and pathogen avirulence gene are now required to deepen understanding of molecular mechanisms involved in the host-pathogen interaction (Valent, 1990).

So far, about 50 major rice blast $R$ genes and 35 avirulence $(A v r)$ genes have been reported. A great number of genes with complete or partial resistance to blast in rice have been mapped and developed so far, which included Pil(t), Pi2(t), Pi4(t), Pi5(t), Pi6(t), Pi9(t), Pi10(t) and Pi11(t) (Causse et al.,1994), Pi5(t) and Pi7(t) (Wang et al., 1994), Pia, Pib, Pik, Pit, Pita, Pi12(t), Pi17(t), Pi18(t), Pi19(t), Pi20(t), Pi23(t), Pi62(t), and Pi157(t) (Nagato and Yoshimura, 1998), Pitq1, Pitq5, Pi-tq6 and Pilm2 (Tabien et al., 2000), the recessive gene pi21 (Fukuoka et al., 2001), the QTLs for partial resistance to leaf blast (Wang et al., 1994) and QTLs for partial resistance to neck blast (Bagali et al., 2000; Sirithunya et al., 2002).

Recently, many rice varieties with complete resistance to $M$. grisea have been developed, but in many cases this resistance has been breakdown within a few years of the initial cultivation owing to the emergence of stronger virulent isolates of rice blast fungus (Bonman et al., 1986; Han et al., 2001; Kiyosawa, 1981; Mackill and Bonman, 1992; Yaegashi, 1994). Partial or field resistance of rice blast has received much attention as a means of effective control of a parasite under natural field condition and conferring durable blast resistance when exposed to new races of that parasite (Hittalmani et al., 2000; Liu et al., 2005; Wang et al., 1994).

This study was carried out to acquire information for genetic diversities of resistance genes against rice blast 
disease in aromatic rice germplasms for improving aromatic rice breeding efficiency using PCR-based markers including several candidate SNP (single nucleotide polymorphisms) markers.

\section{Materials and Methods}

Rice plant materials and DNA extraction. In our previous studies, we described the origin and characteristics of 260 accessions of aromatic rice germplasms introduced from 20 origins and preserved in Korean RDA genebank. Eighty six of 260 aromatic rice accessions were evaluated with agronomic traits, pshycochemical characteristics, and analysis of aromatic compounds in 2007 (Kim et al., 2008a and $\mathrm{Kim}$ et al., 2008b). The eighty six aromatic rice accessions were offered from National Agrobiodiversity Center of RDA, Korea, in Table 2. Five rice seeds of each accession were disinfected with $2 \% \mathrm{NaOCl}$ solution at $4 \mathrm{hrs}$ and were washed with tap water at overnight and placed on moist filter paper laid on the petri-dish at $30^{\circ} \mathrm{C}$ for oneweek in growth chamber.

Genomic DNA was extracted from frozen young leaves of one-week-old seedlings by an improved CTAB (hexadecyl trimethyl ammonium bromide) method based on the procedure described by Murray and Thompson (1980). The extracted genomic DNA was estimated on $1 \%$ agarose gels staining of ethidium bromide for quality test. The quantity of extracted DNA was measured by Nano Drop system (Thermo, U.S.A.) and they were diluted to $10 \mathrm{ng} / \mu \mathrm{l}$ with the sterilized distill water and stored at $4{ }^{\circ} \mathrm{C}$.

SNP markers specific for rice blast $\mathbf{R}$ gene. Table 1, eight PCR based allele-specific SNP marker set (z4792, zt4792, z60510, zt6057, k6415, k6411, k39575 and t256) of 6 major rice blast resistance (R) genes, Piz, Piz-t, Pik, Pik-m, $P i k-p$ and $P i t$, were previously reported another studies (Cho et al., 2007; Hayashi et al., 2004; Hayashi et al., 2006). Two of blast resistance genes, Piz and Piz-t genes, were reported that closed to same position of on chromosome 6, and related to four SNP marker, z4792, zt4792, z60510, and zt6057 (Hayashi et al., 2004).

We used the eight SNP markers for amplification of DNA fragments linked to rice blast resistant genes based on each previous research papers. All of the rice blast resistance markers were synthesized at the oligo synthesis facility of Bioneer Co., in Korea.

Polymerase chain reaction (PCR) analysis. The PCR analysis for the SNP allele-specific markers were conducted based on procedures described by Bioneer PCR Pre-mix kit manual (Bioneer Co. Ltd, Korea). The PCR reaction mixture contained $50 \mathrm{ng}$ of genomic DNA, 5 pmol of each primer set, $2.5 \mathrm{mM}$ of each dNTPs, $1.5 \mathrm{mM} \mathrm{MgCl}_{2}, 1 \mathrm{X}$ PCR buffer (10 mM Tris- $\mathrm{HCl}$, pH 9.0, and $30 \mathrm{mM} \mathrm{KCl})$, and 1 unit of Taq DNA polymerase in $20 \mathrm{ul} \mathrm{PCR} \mathrm{reaction}$ volume. PCR amplifications were carried out in a MyGenie96 Thermal cycler (Bioneer Co. Ltd, Korea), and programmed that template DNA was initially denatured at $95^{\circ} \mathrm{C}$ for $4 \mathrm{~min}$, followed by 30 cycles of PCR amplification steps with the following parameters; a $30 \mathrm{sec}$ denaturation at $94^{\circ} \mathrm{C}, 30 \mathrm{sec}$ primer annealing at from 42 to $62^{\circ} \mathrm{C}$, and a $60 \mathrm{sec}$ primer extension at $72^{\circ} \mathrm{C}$ allowed for completion of primer extension, with a final extension at $72^{\circ} \mathrm{C}$ for $10 \mathrm{~min}$. Initially $4 \mu$ of the amplified products were electrophoretically resolved on a $1.5 \%$ agarose gel in $0.5 \mathrm{X}$ TAE (Tris-acetateEDTA) buffer (pH 8.0) and visualized under UV light after staining with $0.1 \mathrm{ug} / \mathrm{ml}$ of ethidium bromide (Et-Br). The amplified fragment using SNP markers were scored as presence (1) or absence (0) of amplicon linked each gene DNA fragment.

\section{Results}

MAS of rice blast resistance accessions of aromatic rice germplasm. Application of molecular markers will enhance the efficiency of rice evaluation and improvement

Table 1. Details of single nucleotide polymorphisms (SNP) markers tightly linked to the major rice blast resistant genes

\begin{tabular}{|c|c|c|c|c|c|}
\hline \multirow{2}{*}{\multicolumn{2}{|c|}{ Genes }} & \multirow{2}{*}{$\begin{array}{l}\text { Number of } \\
\text { Chromosome }\end{array}$} & \multirow{2}{*}{ Markers } & Primer sequence & \multirow{2}{*}{$\begin{array}{l}\text { Expected size } \\
\text { (bp) }\end{array}$} \\
\hline & & & & Forward $\left(5^{\prime}-3^{\prime}\right)$ & \\
\hline \multirow{4}{*}{$\begin{array}{c}P i z \\
(P i z-t)\end{array}$} & $P i z$ & \multirow{4}{*}{6} & z4792 & cgcacgctttccgaactactcccgct agtgttgtgcggcacgtgctttg & 340 \\
\hline & $P i z-t$ & & zt4792 & tatattttggggcggaggtaggac agtgttgtgcggcacgtgctttg & 340 \\
\hline & Piz, Piz-t & & z60510 & ggagttggtgcgacggtgccgttac gcgcggaccggccagctagttgac & 360 \\
\hline & Piz-t & & zt6057 & gaagctcaaactaggaacgtgacgc actggaagtccctctatatgccc & 360 \\
\hline \multirow{3}{*}{$P i k$} & Pik & & $\mathrm{k} 6415$ & gcattagatagtgatgaaagccgg & 218 \\
\hline & Pik-m & 11 & $\mathrm{k} 6441$ & tgtaaaatactttctatgcgcaggc & 404 \\
\hline & Pik-p & & k39575 & ggtgtttgggaacctgaacccta & 158 \\
\hline Pit & Pit & 1 & $\mathrm{t} 256$ & ggatagcagaagaacttgagacta catgtctttaacataagaagttctc & 322 \\
\hline
\end{tabular}


Table 2. Genotyping of 86 accessions of aromatic rice germplasm estimated with eight of allele-specific SNP markers linked to the major of rice blast resistant gene

\begin{tabular}{|c|c|c|c|c|c|c|c|c|c|c|}
\hline \multirow{2}{*}{ Lanes } & \multirow{2}{*}{ Varieties } & \multirow{2}{*}{ Ecotypes } & $\mathrm{Piz}$ & $P i z-t$ & $P i z, P i z-t$ & $P i z-t$ & $P i k$ & Pik-m & Pik-p & Pit \\
\hline & & & z4792 & zt4792 & z60510 & Zt6057 & K6415 & Pk6441 & K39575 & t256 \\
\hline 1 & Hyangmibyeolho & Tongil & $1^{\mathrm{a}}$ & 1 & 1 & 0 & 1 & 0 & 1 & 1 \\
\hline 2 & Hyangmibyeo2ho & Tongil & 1 & 1 & 1 & 0 & 1 & 1 & 1 & 1 \\
\hline 3 & Hyangnambyeo & Japonica & 1 & 0 & 1 & 1 & 0 & 1 & 1 & 1 \\
\hline 4 & Aranghyangchalbyeo & Japonica & 1 & 0 & 1 & 1 & 0 & 1 & 1 & 1 \\
\hline 5 & Mihayangbyeo & Japonica & 1 & 0 & 1 & 1 & 0 & 1 & 1 & 1 \\
\hline 6 & A-2 & Japonica & 1 & 1 & 1 & 1 & 1 & 1 & 1 & 0 \\
\hline 7 & A-3, Choh Chang & Japonica & 1 & 0 & 1 & 1 & 1 & 1 & 1 & 1 \\
\hline 8 & Muhyang99-8 & Japonica & 0 & 1 & 1 & 1 & 1 & 1 & 1 & 1 \\
\hline 9 & Jahyangna861 & Japonica & 1 & 1 & 1 & 1 & 0 & 1 & 1 & 1 \\
\hline 10 & Jc149 & Japonica & 1 & 0 & 1 & 1 & 1 & 1 & 1 & 1 \\
\hline 11 & Jc157 & Japonica & 1 & 0 & 1 & 1 & 1 & 1 & 1 & 1 \\
\hline 12 & Iari 7447 & Japonica & 1 & 0 & 1 & 1 & 0 & 0 & 1 & 1 \\
\hline 13 & Daebunhyangdo2 & Japonica & 1 & 0 & 1 & 1 & 0 & 0 & 1 & 1 \\
\hline 14 & Shiyayuuine & Japonica & 1 & 0 & 1 & 1 & 0 & 0 & 1 & 1 \\
\hline 15 & Rasomotrafotsy & Japonica & 1 & 0 & 1 & 1 & 1 & 1 & 1 & 1 \\
\hline 16 & TALLI & Japonica & 1 & 0 & 1 & 1 & 1 & 1 & 1 & 1 \\
\hline 17 & Masino Basmati & Japonica & 1 & 0 & 1 & 1 & 1 & 1 & 1 & 1 \\
\hline 18 & Kalomasino Dhan & Japonica & 1 & 0 & 1 & 1 & 1 & 1 & 1 & 1 \\
\hline 19 & Gerdeh & Japonica & 1 & 0 & 1 & 0 & 0 & 1 & 1 & 1 \\
\hline 20 & KINANDANG PAT & Japonica & 1 & 0 & 1 & 1 & 1 & 1 & 1 & 1 \\
\hline 21 & Milagrosa Mutant & Japonica & 1 & 1 & 1 & 1 & 0 & 1 & 0 & 1 \\
\hline 22 & Inaguhu & Japonica & 1 & 0 & 1 & 1 & 1 & 0 & 1 & 1 \\
\hline 23 & Flores & Japonica & 1 & 1 & 1 & 1 & 0 & 1 & 1 & 1 \\
\hline 24 & Kung-ShanWu-Shen-Ken & Japonica & 1 & 1 & 1 & 1 & 0 & 1 & 1 & 1 \\
\hline 25 & Daw Dam & Japonica & 1 & 0 & 1 & 1 & 1 & 1 & 1 & 1 \\
\hline 26 & 415 X Ir352 & Japonica & 1 & 1 & 1 & 0 & 1 & 0 & 1 & 1 \\
\hline 27 & Khau Nua Keo & Japonica & 0 & 0 & 0 & 0 & 0 & 1 & 0 & 1 \\
\hline 28 & Khau Tan Luong & Japonica & 1 & 0 & 1 & 1 & 0 & 1 & 0 & 1 \\
\hline 29 & Goolarath & Indica & 1 & 1 & 1 & 1 & 0 & 1 & 1 & 1 \\
\hline 30 & Da13 & Indica & 1 & 0 & 1 & 1 & 1 & 1 & 1 & 1 \\
\hline 31 & Basmati 370 & Indica & 1 & 0 & 1 & 1 & 1 & 1 & 1 & 1 \\
\hline 32 & Hyanggaengdo & Indica & 1 & 1 & 1 & 0 & 1 & 1 & 1 & 1 \\
\hline 33 & Seratus Malam & Indica & 1 & 0 & 1 & 1 & 1 & 1 & 1 & 1 \\
\hline 34 & Basmati T3 & Indica & 1 & 0 & 1 & 1 & 1 & 1 & 1 & 1 \\
\hline 35 & Jc111 & Indica & 1 & 0 & 1 & 1 & 1 & 1 & 1 & 1 \\
\hline 36 & Arc 6011 & Indica & 1 & 0 & 1 & 1 & 0 & 1 & 1 & 1 \\
\hline 37 & Kaminibhog & Indica & 0 & 1 & 1 & 1 & 1 & 1 & 1 & 1 \\
\hline 38 & Tarana Deshi & Indica & 1 & 1 & 1 & 1 & 1 & 0 & 1 & 1 \\
\hline 39 & Basmati & Indica & 0 & 1 & 1 & 1 & 1 & 1 & 1 & 1 \\
\hline 40 & Iranbyeopssi & Indica & 1 & 0 & 1 & 1 & 1 & 1 & 1 & 1 \\
\hline 41 & Iranbyeopssi & Indica & 1 & 0 & 1 & 1 & 1 & 0 & 1 & 1 \\
\hline 42 & Domsiah & Indica & 1 & 0 & 1 & 1 & 1 & 1 & 1 & 1 \\
\hline 43 & Mulai & Indica & 1 & 0 & 1 & 1 & 1 & 1 & 1 & 1 \\
\hline 44 & Tareme & Indica & 1 & 0 & 1 & 1 & 1 & 1 & 1 & 1 \\
\hline 45 & Hyangdo & Indica & 1 & 0 & 1 & 1 & 1 & 1 & 1 & 1 \\
\hline 46 & Seratus Malam & Indica & 1 & 0 & 1 & 1 & 1 & 1 & 1 & 1 \\
\hline 47 & Mayataung & Indica & 1 & 1 & 1 & 1 & 1 & 1 & 1 & 1 \\
\hline 48 & Yekywin Yinkya Hmwe & Indica & 1 & 1 & 1 & 1 & 1 & 1 & 1 & 1 \\
\hline
\end{tabular}


Table 2. Continued

\begin{tabular}{|c|c|c|c|c|c|c|c|c|c|c|}
\hline \multirow{2}{*}{ Lanes } & \multirow{2}{*}{ Varieties } & \multirow{2}{*}{ Ecotypes } & $P i z$ & $P i z-t$ & $P i z, P i z-t$ & $P i z-t$ & $P i k$ & Pik-m & Pik-p & Pit \\
\hline & & & z4792 & zt4792 & z60510 & zt6057 & k6415 & k6441 & k39575 & $\mathrm{t} 256$ \\
\hline 49 & Kala Namak & Indica & 1 & 0 & 1 & 1 & 1 & 1 & 1 & 1 \\
\hline 50 & Masino Basmati & Indica & 0 & 1 & 1 & 1 & 1 & 1 & 1 & 1 \\
\hline 51 & Basmati Dhan & Indica & 1 & 0 & 1 & 1 & 1 & 0 & 1 & 1 \\
\hline 52 & Basmati & Indica & 1 & 1 & 1 & 1 & 1 & 0 & 1 & 1 \\
\hline 53 & Basmati 370 & Indica & 0 & 0 & 1 & 1 & 1 & 1 & 1 & 1 \\
\hline 54 & Basmati 9-93 & Indica & 1 & 1 & 1 & 1 & 1 & 1 & 1 & 1 \\
\hline 55 & Basmati 198 & Indica & 1 & 0 & 1 & 1 & 1 & 1 & 1 & 1 \\
\hline 56 & Basmati 370 & Indica & 1 & 0 & 1 & 1 & 1 & 1 & 1 & 1 \\
\hline 57 & Basmati 5836 & Indica & 1 & 1 & 1 & 0 & 1 & 1 & 1 & 1 \\
\hline 58 & Basmati 5854 & Indica & 1 & 1 & 1 & 1 & 1 & 1 & 1 & 1 \\
\hline 59 & Basmati 5875 & Indica & 1 & 0 & 1 & 1 & 1 & 1 & 1 & 1 \\
\hline 60 & Basmati 6113 & Indica & 1 & 1 & 1 & 0 & 0 & 1 & 1 & 1 \\
\hline 61 & Basmati 1 & Indica & 1 & 0 & 1 & 1 & 1 & 1 & 1 & 1 \\
\hline 62 & Basmati $213 \mathrm{C}$ & Indica & 1 & 0 & 1 & 1 & 1 & 1 & 1 & 1 \\
\hline 63 & Basmati 372 & Indica & 1 & 0 & 1 & 1 & 1 & 1 & 1 & 1 \\
\hline 64 & Chahora 144 & Indica & 1 & 0 & 1 & 1 & 1 & 1 & 1 & 1 \\
\hline 65 & Pakistani Fine & Indica & 0 & 0 & 1 & 1 & 1 & 1 & 1 & 1 \\
\hline 66 & Ir841-85-1-1-2 & Indica & 1 & 1 & 1 & 0 & 1 & 1 & 1 & 1 \\
\hline 67 & 05-Irri-M-46 & Indica & 1 & 0 & 1 & 1 & 1 & 1 & 1 & 1 \\
\hline 68 & Basmati 107 & Indica & 1 & 0 & 1 & 1 & 1 & 1 & 1 & 1 \\
\hline 69 & Basmati 405 & Indica & 1 & 0 & 1 & 1 & 1 & 1 & 1 & 1 \\
\hline 70 & Basmati 5853 & Indica & 1 & 1 & 1 & 0 & 1 & 1 & 1 & 1 \\
\hline 71 & Basmati 5874 & Indica & 1 & 0 & 1 & 1 & 1 & 1 & 1 & 1 \\
\hline 72 & Basmati 6129 & Indica & 0 & 0 & 1 & 1 & 0 & 0 & 1 & 1 \\
\hline 73 & Basmati 6311 & Indica & 1 & 0 & 1 & 1 & 0 & 1 & 0 & 1 \\
\hline 74 & Basmati 6313 & Indica & 1 & 1 & 1 & 0 & 1 & 1 & 1 & 1 \\
\hline 75 & Basmati 6141 & Indica & 1 & 1 & 1 & 0 & 1 & 1 & 1 & 1 \\
\hline 76 & AZUCENA & Indica & 1 & 0 & 1 & 1 & 0 & 1 & 1 & 1 \\
\hline 77 & Binicol & Indica & 0 & 0 & 1 & 1 & 1 & 1 & 1 & 1 \\
\hline 78 & Milfor 6 & Indica & 1 & 1 & 1 & 1 & 0 & 1 & 1 & 1 \\
\hline 79 & Dinorado & Indica & 1 & 0 & 1 & 1 & 0 & 1 & 0 & 1 \\
\hline 80 & Khao Dawk Mali105 & Indica & 1 & 1 & 1 & 1 & 0 & 1 & 1 & 1 \\
\hline 81 & Jasmine 85 & Indica & 0 & 1 & 1 & 0 & 1 & 1 & 1 & 1 \\
\hline 82 & Dellmont & Indica & 1 & 0 & 1 & 1 & 0 & 1 & 1 & 1 \\
\hline 83 & Aroma & Indica & 1 & 0 & 1 & 1 & 0 & 1 & 1 & 1 \\
\hline 84 & Ds20 & Indica & 0 & 1 & 1 & 0 & 1 & 1 & 1 & 1 \\
\hline
\end{tabular}

a: The rice blast resistant genes scored as the presence (1) or absence (0) of amplicons linked to eight of allele specific SNP markers.

program. Eighty four accessions of aromatic rice germplasm were screened for the presence of 6 major rice blast resistance (R) genes, Piz, Piz-t, Pik, Pik-m, Pik-p, and Pit, using the eight of SNP markers listed in Table 1. An allele specific PCR marker assays the genotype of SNP marker by estimating the presence or absence of PCR amplicon from a pair of PCR reactions.

All of the eighty four accessions of aromatic rice germplasms possessed at least more than three positive bands of the eight rice blast resistance markers in Table 2. Indica type of four accessions, Mayataung, Yekywin Yinkya Hmwe, Basmati9-93, and Basmati5854, showed the positive amplicon of 6 major rice blast resistance genes (Table 2).

Genetic diversity of Piz and Piz-t gene. Estimation of PCR results for the Piz and Piz-t rice blast resistance genes were determined by visualization of amplicons on $340 \mathrm{bp}$, $240 \mathrm{bp}$, and $360 \mathrm{bp}$ of positive fragments using two set of SNP primer, set 1 (z4792 and zt4792) and set2 (z60510 and zt6057) (Fig. 1). Piz gene on chromosome 6 was scored to 

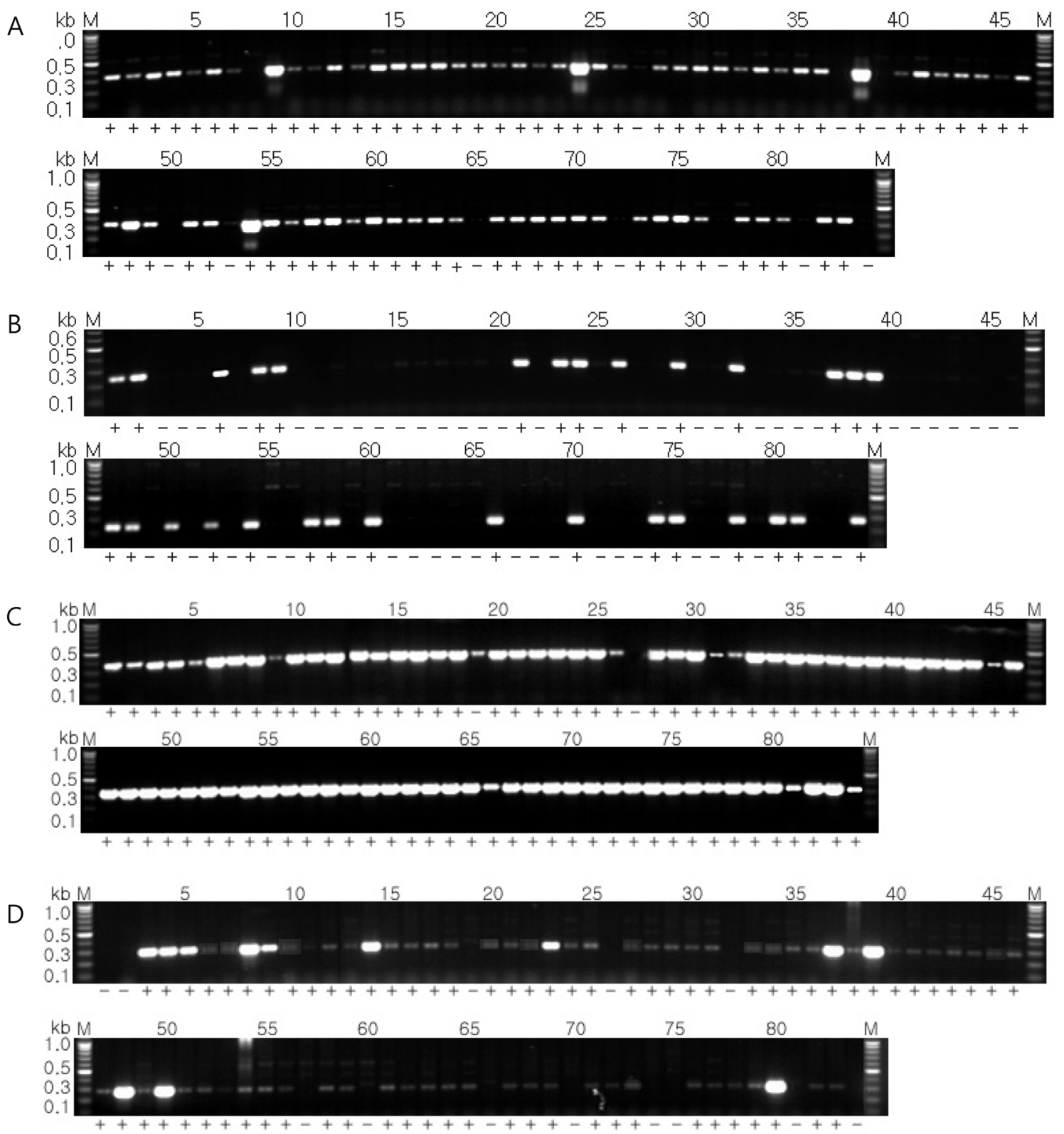

Fig. 1. Electrophoretical band patterns of PCR products for 84 aromatic rice germplasms. The amplified fragments using SNP markers, z4792 (A), zt4792 (B), z60510 (C), and zt6057 (D), were scored as presence (+) or absence (-) of amplicons linked to Piz gene. M, molecular marker (Bioneer $100 \mathrm{bp}$ ladder plus); lanes 1-84, eighty four accessions of aromatic rice.

73 accessions of aromatic rice germplasm, two accessions of two accessions of tongil type, twenty four accessions of japonica type, and forty seven accessions of indica type (Fig. 1).

Piz-t gene on chromosome 6 was detected in eighty three accessions of aromatic rice germplasm with together or any one of zt4792 and zt6057 SNP marker. Among the eighty three, thirty accessions and seventy one accessions were amplified with each one of allele specific SNP marker, zt4792 and zt6057, respectively. Eighteen accessions including six of japonica type and twelve of indica type showed the positive bands with both zt4792 and zt6057 SNP markers (Fig. 1).

Eighty three accessions possessed at least one genes of Piz and Piz- $t$ genes identified with SNP marker z60510. And only one accession, Khau Nua Keo, was not amplified any one of Piz and Piz-t gene with four SNP markers. But japonica type aromatic rice, Gerdeh, possessed only Piz gene (Fig. 1).

Genetic diversity of Pik multi gene. Fifty two accessions show the positive reactions of all of three Pik multiple 


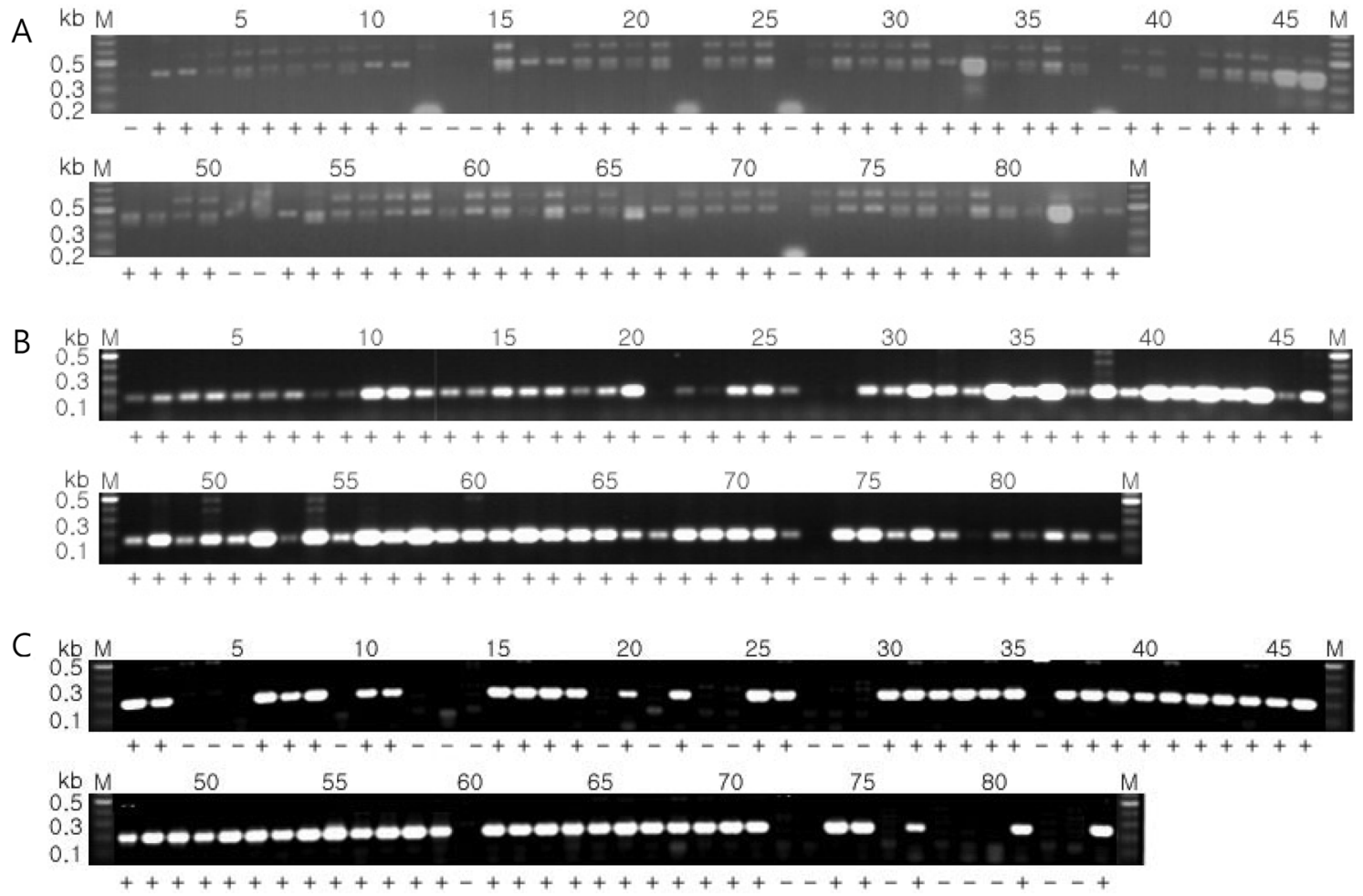

Fig. 2. $P C R$ analysis of 84 aromatic rice germplasms to evaluate rice blast resistance genes. Pik multi genes, $P i k$ (A), Pik-m (B), and $P i k$ $p(\mathrm{C})$, were scored as presence $(+)$ or absence $(-)$ of target amplicon. Each gene of Pik multi genes amplified with allele specific SNP markers, k6441 (Pik), k39575 (Pik-m), and k6415 (Pik-p) M, molecular marker (Bioneer 100 bp ladder plus); lanes 1-84, eighty four accessions of aromatic rice.

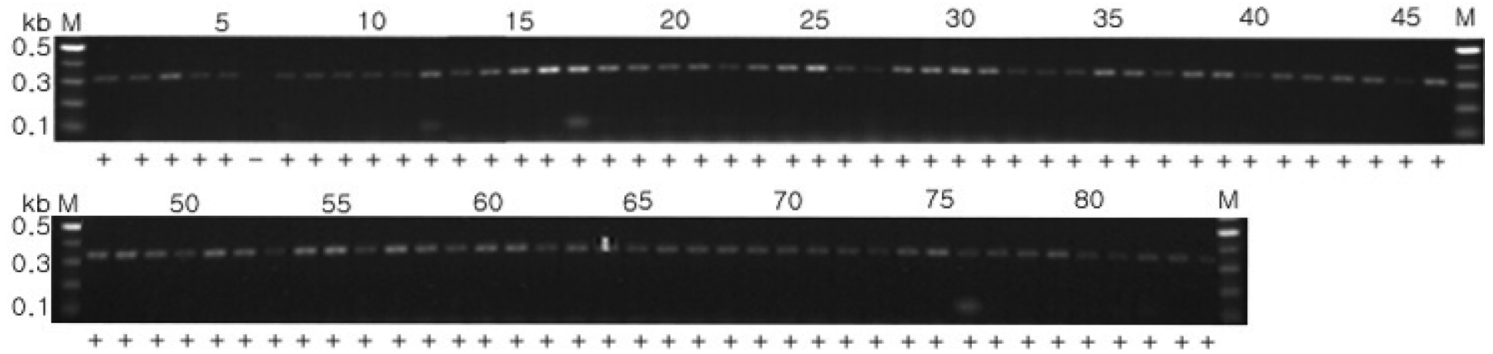

Fig. 3. Agarose gel photograph of 84 aromatic rice germplasms for the SNP morker $t 256$ sized $322 \mathrm{bp}$. The presence of the amplicon was scored as presence (1) or absence (0) of amplicon linked Pit gene. M, molecular marker (Bioneer 100 bp ladder plus); lanes 1-84, eighty four accessions of aromatic rice.

genes, Pik, pik-p, and Pik-m, located on chromosome 11 with tightly linked three SNP markers k6415, k6441, and k39575. Among the eighty four accessions, four accessions, Iari7447, Daebunhyangdo2, Shiyayuuine, and Basmati 6129 possessed only Pik- $p$ gene of three Pik multi genes (Fig. 2). Three accessions of japonica type (Milagrosa mutant, Khau Nua Keo, and Khau Tan Luong) and two accessions of indica type (Basmati6311 and Dinorado) were showed the positive ampilcon for Pik-m of three Pik multi genes with k6441 SNP marker. Each of the seven accessions of japonica type (Hyangnambyeo, Arnahyangchalbyeo, Mihayangbyeo, Jahyangna86-1, Gerdeh, Flores, and Kung-Shan Wu-Shen-Ken) and indica type (Goolarath, Arc6011, Azucena, Milfor6, Khao Dawk Mali 105, Aroma, and Ds20) aromatic rice germplasms was possessed the positive bands of Pik-m and Pik-p genes. Allele specific resistance genes of $P i k$ and $P i k-p$ gene were detected in three accessions of japonica type (Hyangmibyeolho, Inaguhu, and 415xIr352) and four accessions of indica type (Tarana Deshi, Iranbyeopssi, Basmati Dhan, and Basmati), respectively (Fig. 2).

Genetic diversity of Pit gene. Especially, one of the NBSLRR family genes, Pit gene founded on chromosome 1 of 
indica rice variety $\mathrm{K} 59$, was detected as 322 bp of positive bands in all of 83 accessions of aromatic rice germplasm with t256 SNP marker, exception A-2, one of japonica type (Fig. 3).

\section{Discussion}

In Asian cultivated rice, aroma is one of the most valuable traits in grain quality. The rice world market ranks aromatic rice at the top and for the $4 \sim 5$ million tons of aromatic rice worth 2 2.5 billion US Dollars traded in the world and the greatest market will become more competitive in the near future (McCouch et al., 2007; Singh et al., 1997).

Recently, more than 50 major blast resistance genes have been identified (Chauhan et al., 2002; Chen et al., 2002; Berruyer et al., 2003; Liu et al., 2004; Liu et al., 2005; Pan et al., 1999; Sallaud et al., 2003; Wu et al., 2003; Zhu et al., 2004). However, a number of blast resistance genes below have been mapped, which should be regarded as an essential starting point to isolate these important genes through map-based cloning approach.

Plant breeders often use cultivars developed in other countries to broaden the genetic background of the improved cultivars being developed such as the major fungal diseases of last and sheath blight. But most breeding programs of aromatic rice have a narrow genetic diversity of breeding resources (Khush, 1981). In Pakistan, out of 7 basmati varieties were currently under cultivation, five had 'Basmati 370' as one of the parent cultivar (Arif et al., 2005). Also, in Korea, only seven varieties of aromatic rice were bred and distributed as cultivars. Most of these varieties have a parent originated from Japan (Dohoku144 and Miyagaori) and IRRI (IR841-76-1), exception of Heughyangbyeo that was mutated Sanghaehyanghyeolla with 300Gy of $\gamma$-ray (Choi et al., 1995; Ha et al., 2003; Ha et al., 2006; Moon et al., 2003).

Our results, the genetic frequency of the six major rice blast resistance genes, Piz, Piz-t, Pik, Pik-m, Pik-p, and Pit, ranged from $30 \%$ to $99 \%$. Significantly, eighty three accessions (99\%) were detected with both or one of Piz and Piz$t$ genes. Ten accessions (12\%) showed the positive bands for the Piz-t gene with both zt4792 and zt6057 SNP markers. Only one accession, Khau Nua Keo, was not amplified with both Piz and Piz-t gene with four SNP markers. Especially, japonica type aromatic rice, Gerdeh, possessed only Piz gene between Piz and Piz-t.

Both Piz and Piz-t genes have been used for conferring blast resistance to Japanese cultivars, because their importance was emphasized by Hayashi et al. (2004) in rice breeding in Japan. The previous studies described that Niigatawase, a resistant donor cultivar of Piz, and Toride 1, a resistant donor cultivar of Piz-t. The Piz gene was mapped close to Piz-t on chromosome 6 of Japanese indica rice variety $\mathrm{K} 59$.

The Piz- $t$ and Piz genes, co-segregated with zt4792 and zt6057 markers, was flanked on one side by z 4794 with one recombination and on the other side by z60510 and z5765 markers with two combinations. Also, the Piz gene cosegregated with three markers, z4792, z60510, and z5765. The gene was flanked on one side by z6050 and z4794 markers with one combination and on the other side by marker z3943 with two combinations (Hayashi et al., 2004).

Hayashi et al. (2006) revealed that three alleles of the Pik locus, Pik, Pik-p and Pik-m are mapped on the same chromosomal region by linkage analysis using 300 to 2,100 $\mathrm{F}_{2}$ segregation populations.

The genes Pik and Pik-m originated in the Chinese japonica cultivars To-To (Kiyosawa, 1968) and Hokushi Tami (Kiyosawa, 1978), respectively, whereas Pik-p originated in the indica cultivar Pusur (Kiyosawa, 1969a). With exception of Pik-s, the Pik multi resistance genes to distinct rice blast isolates are similar. The resistance specificities of $P i k$ and $P i k-m$ mostly overlap each other and show a similar resistance response to distinct blast isolates. But $P i k-m$ has a broader resistance spectrum than $P i k$ and is composed of two, or more than two, genetic factors (Ashikawa et al., 2008; Kiyosawa and Nomura, 1988).

In this study, fifty two accessions showed the three of Pik multiple genes and Pit gene. Four accessions, Iari7447, Daebunhyangdo2, Shiyayuuine, and Basmati 6129 possessed only a $P i k-p$ gene of $P i k$ multi genes.

Pit gene was reported as a major resistance gene on chromosome 1 which is inherited from an indica rice variety K59 and confers essential race-specific resistance against the fungal pathogen, Magnaporthe grisea, and is a member of the nucleotide-binding site-leucine-rich repeat (NBS-LRR) family of evolution R genes (Hayashi et al., 2006).

Cho et al. (2007) described that none of the Korean rice varieties was found to be have positive bands of the Pit gene, with t256 SNP marker. But the tested Korean rice varieties were non-aromatic rice varieties. Pit gene was founded in an indica rice variety K59. Fortunately in our results, Pit gene was detected all of 83 accessions of aromatic rice germplasms, two tongil types, twenty five japonica types, and fifty six indica types, and expected one accession of japonica type, A-2, and originated from Bhutan.

The host $\mathrm{R}$ genes and pathogen avirulence genes of rice blast fungus and rice plant are required to deepen understanding of molecular mechanisms involved in the hostpathogen interaction. But, the molecular marker is a useful tool for assessing genetic variations and resolving cultivar identities. 
In our study, four accessions of indica type, Mayataung, Yekywin Yinkya Hmwe, Basmati9-93, and Basmati5854, showed the positive bands to six major rice blast resistance genes, Piz, Piz-t, Pik, Pik-m, Pik-p, and Pit. The origins of four candidate accessions possessed to China, Myanmar, and Pakistan.

Transferring blast resistance genes to different genetic backgrounds is very cumbersome and tedious. Since it would be difficult to identify under field conditions using conventional approaches in order for marker-assisted selection to facilitate at early selection phase with greater accuracy (Gu et al., 2005; Melchinger et al., 1990; Mohan et al., 1997).

In this study, the marker-assisted selection of rice blast resistance genes will help in the breeding program in multi diseases resistant aromatic rice varieties in genetic resources of aromatic rice. Some of these germplasma may have special properties that are important to breeding program whereas others may possess proprietary technology.

\section{Acknowledgement}

This research was supported by a grant program (200901FHTO2060950301) funded by Rural Development Administration (RDA), Republic of Korea in 2009.

\section{References}

Arif, M., Kousar, S., Bajwa, M. A., Arif, A. and Zapar, Y. 2005. Genetic diversity among rice genotypes of Pakistan through random amplified polymorphic DNA (RAPD) analysis. Pakistan Journal of Botany 37:585-592.

Ashikawa, I., Hayashi, N., Yamane, H., Kanamori, H., Wu, J., Mastsumoto, T. and Yano, M. 2008. Two adjacent nucleotidebinding site-leucine-rich repeat class genes are required to confer Pikm-specific rice blast resistance. Genetics 180:22672276.

Bagali, P. G., Hittalmani, S., Shashidhar, S. Y. and Shashidhar, H. E. 2000. Identification of DNA markers linked to partial resistance for blast disease in rice across four locations. In: Advances in Rice Blast Research, D. Tharreau, M. H. Lebrun, N. J. Talbot, and J. L. Notteghem, eds. pp. 34-44. Kluwer Academic Publishers, Dordrecht, Netherlands.

Berruyer, R., Adreit, H., Milazzo, J., Gaillard, S., Berger, A., Dioh, W., Lebrun, M. H. and Tharreau, D. 2003. Identification and fine mapping of Pi33, the rice resistance gene corresponding to the Magnaporthe grisea avirulence gene ACE1. Theor. Appl Genet. 107:1139-1147.

Bonman, J. M., Dedios, T. I. V. and Khin, M. M. 1986. Physiological specialization of Pyricularia ortzae in the Philippines. Plant Dis. 70:767-769.

Causse, M. A., Fulton, T. M., Cho, Y. G., Ahn, S. N., Chunwongse, J., Wu, K. S., Xiao, J. H., Yu, Z. H., Ronald, P. C., Harrington, S. E., Second, G., McCouch, S. and Tanksley, S.
D. 1994. Saturated molecular map of the rice genome based on an interspecific backcross population. Genetics 138:12511274.

Chauhan, S., Farman, M. L., Zhang, H. B. and Leong, N. 2002. Genetic and physical mapping of a rice blast resistance locus, $\operatorname{PiCO39}(\mathrm{t})$, that corresponds to the avirulence gene AVRICO39 of Magnaporthe grisea. Mol. Genet. Genomics 267: 603-612.

Chen, M., Presting, G. and Barbazuk, W. B. 2002. An integrated physical and genetic map of the rice genome. Plant Cell 14:537-545.

Cho, Y. C., Kwon, S. W., Choi, I. S., Lee, S. K., Jeon, J. S., Oh, M. K., Roh, J. H., Hwang, H. G., Yang, S. J. and Kim. Y. G. 2007. Identification of major blast resistance genes in Korean rice varieties (Oryza sativa L.) using molecular markers. J. Crop Sci. Biotech. 10:265-276.

Choi, Y. G., Kim, M. K., Jung, K. H., Cho, S. Y., Moon, H. P., Jun B. T., Choi, H. C., Park, N. G., Kim, G. W., Hwang, K. H., Kim, Y. S., Park, R. K. and Cho, J. Y. 1995. An aromatic semidwarf lodging resistant rice variety "Hyangmibyeolho". Agricultural Science Reports of RDA, Korea. 37:67-74.

Fukuoka, S. and Okuno, K. 2001. QTL analysis and mapping of $P i 21$, a recessive gene for field resistance to rice blast in Japanese upland rice. Theor. Appl. Genet. 103:185-190.

Gu, K., Yang, B., Tian, D., Wu, L., Wang, D., Sreekala, C., Yang, F., Chu, Z., Wang, G. L., White, F. F. and Yin, Z. 2005. $R$ gene expression induced by type-III effecter triggers disease resistance in rice. Nature 435:1122-1125.

Ha, K. Y., Kim, Y. D., Lee, J. K., Shin, H. T., Noh, T. H., Choung, J. I., Shin, M S., Ko, J. K., Kim, B. K., Lee, Y. T., Lee, S. Y., Kim, H. S., Kang, H. J., Lee, K. S. and Lee, S. Y. 2003. A new aromatic and high-yielding Japonica rice cultivar "Mihyangbyeo". Korean J. Breed. Sci. 35:251-252.

Ha, K. Y., Lee, J. K., Shin, H. T., Lee, S. Y., Yang, B. G., Kim, B. K., Joung, J. I., Kim, Y. D., Shin, M. S., Ko, J. K., Lee, K. S., Kim, C. H. and Cho, S. Y. 2006. A new aromatic and good grain quality Japonica rice variety "Hyangnambyeo". Agricultural Science Reports of RDA, Korea 38:54-60.

Han, S. S., Ryu, J. D., Shim, H. S., Lee, S. W., Hong, Y. K. and Cha, K. H. 2001. Breakdown of resistant cultivars by new race $\mathrm{KI}-1117 \mathrm{a}$ and race distribution of rice blast fungus during 1999-2000 in Korea. Res. Plant Dis. 7:86-92 (in Korean, English summary).

Hayashi, K., Yoshida, H. and Ashikawa, I. 2006. Development of PCR-based allele specific and InDel marker sets for nine rice blast resistance genes. Theor. Appl. Genet. 113:251-260.

Hayashi, K., Hashimoto, N., Daigen, M. and Ashikawa, I. 2004. Development of PCR-based SNP markers for rice blast resistance genes at the Piz locus. Theor. Appl. Genet. 108:1212220.

Hittalmani, S., Parco, A., Mew, T. V., Zeigler, R. S. and Huang, N. 2000. Fine mapping and DNA marker-assisted pyramiding of the three major genes for blast resistance in rice. Theor. Appl. Genet. 100:1121-1128.

Khush, G. S. 1981. Breeding rice for multiple disease and insect resistance. In: Rice improvement in China and other Asian 
countries. pp. 220-237. International Rice Research Institute, Los Banos, Philippines.

Kim, J. S., Ahn, S. N., Cho, Y. H., Gwag, J. G., Kim, T. S., Lee, J. R. and Lee, S. Y. 2008a. Estimation of agronomic characteristics of domestic aromatic rice germplasm and foreign aromatic rice germplasm in RDA Genebank, Korea. Korean J. Crop Sci. 53:261-272.

Kim, J. S., Ahn, S. N., Kang, H. K., Cho, Y. H., Gwag, J. G. and Lee, S. Y. 2008b. Estimation of Physico-chemical Characteristics of domestic aroma rice and foreign aroma rice. Korean $J$. Crop Sci. 53:203-216.

Kiyosawa, S. 1968. Inheritance of blast-resistance in some Chinese rice varieties and their derivatives. Jpn. J. Breed. 18:183204.

Kiyosawa, S. 1969. Inheritance of resistance of rice varieties to a Philippine fungus strain of Pyricularia oryzae. Jpn. J. Breed. 19:61-73.

Kiyosawa, S. 1978. Inheritance of blast-resistance in some rice varieties. Jpn. J. Breed. 28:287-296

Kiyosawa, S. and Nomura, K. 1988. Disease resistance in crop plants and mutational breeding. Gamma Field Symposia No. 27. Institute of Radiation breeding, NIAR, MAFF, Ibaraki, Japan.

Kiyosawa, S. 1981. Gene analysis for blast resistance. Oryza 18:196-203.

Kwon, J. O. and Lee, S. G. 2002. Real-time micro-weather factors of growing field to the epidemics of rice blast. Res. Plant Dis. 8:199-206. (in Korean, English abstract).

Lee, F. N. 1994. Rice breeding programs, blast epidemics and blast management in the United States. In: Rice blast disease, ed. Ziegler, R. S. pp. 489-500. C.A.B. International Wallingford, U.K.

Li, Y. B., Wu, C. J., Jiang, G. H., Wang, L. Q. and He, Y. Q. 2007. Dynamic analyses of rice blast resistance for the assessment of genetic and environmental effects. Plant Breeding 126:541547.

Liu, B., Zhang, S. H., Zhu, X. Y., Yang, Q. Y., Wu, S. Z., Mei, M. T., Mauleon, R., Leach, J., Mew, T. and Leung, H. 2004. Cadidate defense genes as predictors of quantitative blast resistance in rice. Mol. Plant Microbe. Interact. 17:1146-1152.

Liu, X. Q., Wang, L., Chen, S., Lin, F. and Pan, Q. H. 2005. Genetic and physical mapping of Pi36(t), a novel rice blast resistance gene located on rice chromosome 8. Mol. Genet. Genomics DOI10.1007/s0048-005-0032-5.

Mackill, D. J. and Bonman, J. M. 1992. Inheritance of blast resistance in near-isogenic lines of rice. Phytopathology 82:746749.

McCouch, S. R., Sweney, M., Li, J., Jiang, H., Thoson, M., Septiningish, E., Edwards, J., Moncada, P., Xiao, J., Garris, A., Tai, T., Martinez, C., Thome, J., Sugiono, M., McClung,A., Yuan L. P. and Ahn, S. N. 2007. Through the genetic bottleneck: $O$. rufipogon as a source of trait enhancing alleles for $O$. sativa. Euphytica 154:317-339.

Melchinger, A. E. 1990. Use of molecular markers in breeding for oligogenic disease resistance. Plant Breed. 104:1-19.

Mohan, M., Nair, S., Bhagwat, A., Krishna, T. G., Tano, M.,
Bhatia, C. R. and Sasaki, T. 1997. Genome mapping, molecular markers and marker-assisted selection in crop plants. Mol. Breed. 3:87-103.

Moon, H. P., Choi, Y. G., Jeong, G. H., Hwang, G. H., Lee, J. H., Kim, M. G., Cho, S. Y., Jeon, B. T., Kim, J. I., Hwang, H. G., Choi, H. C., Park, R. G. and Kim, Y. S. 1998. A new variety, multi disease resistant and semi-dwarf aromatic rice cultivar "Hangmibyeo 2ho". Agricultural Science Reports of RDA, Korea. 40:34-40.

Moon, H. P., Jung, K. K., Choi, Y. G., Lee, J. H., Hwang, H. G., Kim, M. K., Yang, S. J., Hwang, K. H., Song, M. T., Hong, H. C., Shin, Y. S., Kim, H. Y., Ryu, H. Y., Choi, H.C. and Chung, M. N. 2003. A new aromatic and glutinous rice cultivar "Seolhyangchalbyeo". Korean J. Breed. Sci. 35:241-242.

Nagato, Y. and Yoshimura, A. 1998. Report of the committee on gene symbolization, nomenclature and linkage groups. $R G N$ 15: $13-74$.

Ou, S. H. 1979. Breeding rice of resistance to blast, a critical view. In: Proceeding of the Rice Blast Workshop, pp. 79-137. International Rice Research Institute, Manila, Philippines,

Ou, S. H. 1985. Rice disease, 2nd ed. Commonwealth Mycological Institute.

Pan, Q. H., Wang, L. and Tanisaka, T. 1999. A new blast resistance gene identified in the Indian native rice cultivar Aus373 through allelism and linkage tests. Plant Pathol. 48:288-293.

Sallaud, C., Lorieux, M., Roumen, E., Tharreau, D., Berruyer, R., Svestasrani, p., Garsmeur, O., Ghesquiere, A. and Notteghem, J. L. 2003. Identification of five new blast resistance genes in the highly blast-resistant rice variety IR64 using a QTL mapping strategy. Theor. Appl. Genet. 106:794-803.

Singh, V. P., Khush, G. S. and Delaruz, N. 1997. Variability and quality indices in aromatic rice germplasm. IRRN 22:22.

Sirithunya, P., Tragoonrung, S., Vanavichit, A., Pa-In, N., Vongsaprom, C. and Toojinda, T. 2002. Quantitative trait loci associated with leaf and neck blast resistance in recombinant inbred line population of rice (Oryza sativa). DNA Research 9:79-88

Tabien, R. E., Li, Z., Paterson, A. H., Marchetti, M. A., Stansel, J. W. and Pinson, S. R. M. 2000. Mapping of four major rice blast resistance genes from 'Lemont' and 'Teqing' and evaluation of their combinatorial effect for field resistance. Theor. Appl. Genet. 101:1215-1225.

Teng, P. S., Klein-debbinck, H. W. and Pinnschmidt, H. 1991. An analysis of the blast pathosystem to guide modeling and foresting In: Rice blast Modeling and Foresting, pp. 2-5. IRRI.

Valent, B. 1990. Rice blast as a model system for plant pathology. Phytopathology 80:33-36.

Valent, B. and Chumley, F. G. 1994. A virulence genes and mechanism of genetic instability in the rice blast fungus. In: Rice blast disease, eds. Zeigler, R. S., Leong, S. A. and Teng, P. S., eds. pp.111-134. CAB International, Wallingford.

Wang, G. L., Mackill, D. J., Bonman, J. M., McCouch, S. R., Champoux, M. C. and Nelson, R. J. 1994. RFLP mapping of genes conferring complete and partial resistance to blast in a durably resistant rice cultivar. Genetics 136:1421-1434.

Wu, J. Z., Mizuno, H., Hayshi-Tsugane, M., ItoY., Chiden, Y., 
Fujisawa, M., Katagiri, S., Saji, S., Yoshiki, S., Karasawa, W., Yoshihara, R., Hayashi, A., Hobayashi, H., Ito, K., Hamada, M., Okamoto, M., Ikeno, M., Ichikawa, Y., Katayose, Y., Yano, M., Matsumoto, T. and Sasaki, T. 2003. Physical maps and recombination frequency of six rice chromosomes. Plant J. 36:720-730.

Xia, J. Q., Correll, J. C., Lee, F. N., Marchetti, M. A. and Rhoads, D. D. 1993. DNA fingerprinting to examine micro geographic variation in the Magnaporhe grisea (Pyricularia grisea) popu- lation in two rice fields in Arkansas, Phytopathology 83:10291035.

Yaegashi, H. 1994. Use of resistant varieties and disease control for paddy rice. Agric. Hortic. 69:149-154.

Zhu, M. L., Wang, L. and Pan, Q. H. 2004. Identification and characterization of a new blast resistance gene located on rice chromosome 1 through linkage and differential analysis. Phytopathology 94:515-519. 